\title{
ERRATUM
}

\section{Sustainability in Action in Early Childhood Settings - ERRATUM}

Gregory Lowan-Trudeau

Teaching Solutions, Blairgowrie, 2015

Reviewed by Margaret Sear, Queensland Early Childhood Sustainability Network Inc., Queensland, Australia

doi:10.1017/aee.2018.37, first published online by Cambridge University Press on 16 October 2018.

In the above mentioned book review, Gregory Lowan-Trudeau Teaching Solutions was incorrectly cited as author of Sustainability in Action in Early Childhood Settings.

The correct authors of this title are Sally Sneddon and Anne Pettit. Cambridge University Press apologises for the error and any inconvenience caused.

\section{Reference}

Sear, M. (n.d.). Sustainability in Action in Early Childhood Settings. Australian Journal of Environmental Education, 1-3. 